\title{
Emisi Metan Sektor Pertanian Kampung Iklim Desa Mukti Jaya Kecamatan Rimba Melintang Kabupaten Rokan Hilir Provinsi Riau
}

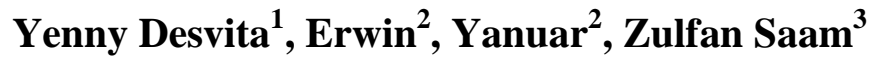 \\ ${ }^{1}$ SMAN 1 Bangko Jalan Gedung Nasioanal Bagansiapiapi, Rokan Hilir.E-mail: yheanie@gmail.com \\ ${ }^{2}$ Fakultas FMIPA Universitas Riau Kampus Bina widya Panam KM 12.5 Pekanbaru. \\ ${ }^{3}$ Program Studi Magister Ilmu Lingkungan Program Pascasarjana Universitas Riau Jalan Pattimura No.09 \\ Gedung.I Gobah Pekanbaru, Telp. 0761-23742
}

\begin{abstract}
Methane emissions of agriculture sector in Indonesia from year to year increase. To reduce the rate of methane emissions increase, the Indonesian government in 2012 through the Ministry of Environment launched the Kampung Iklim program. One of the villages included in Kampung Iklim Program is Mukti Jaya Village, Rimba Melintang Subdistrict, Rokan Hilir Regency, Riau Province. This research aims to analyze methane emission model of agriculture. The research was conducted through survey by field research method. Research location in Mukti Village Rimba Melintang District Rokan Hilir Regency Riau Province. The value of methane rice land emissions in Mukti Jaya Village from 20112015 has increased due to changes in some methane producing parameters. The use of Cisadane varieties produced the highest methane emissions compared to the Ciherang and Dodokan varieties of $0.00029 \mathrm{Gg} \mathrm{CH}_{4}$ year/ ha.
\end{abstract}

Key Words: Methane Emissions, Agricultural Sector, Climate Villages.

Menurut United States Enviromental Protection Agency (2006), emisi sektor pertanian Indonesia pada tahun 2005 mencapai 141 juta ton karbon ekuivalen $\left(\mathrm{MtCO}_{2} \mathrm{e}\right)$. Sementara negara lain seperti Amerika Serikat mencapai $442 \mathrm{MtCO}_{2} \mathrm{e}$, Cina 1,1171 $\mathrm{MtCO}_{2} \mathrm{e}$, Brazil $598 \mathrm{MtCO}_{2} \mathrm{e}$ dan India $442 \mathrm{MtCO}_{2} \mathrm{e}$ pada tahun yang sama, emisi dari sektor pertanian Indonesia termasuk kecil. Emisi ini diprediksi akan terus meningkat pada masa mendatang karena meningkatnya kebutuhan akan pangan (Mulyadi, 2014). Peningkatan emisi gas rumah kaca antara lain disebabkan oleh penggunaan lahan marginal, penggunaan pupuk dari kotoran ternak, peningkatan konsumsi daging dan kebijakan perdagangan internasional yang menyebabkan penggunaan energi untuk transportasi (Zhang, 2010). Oleh karena itu pengurangan emisi gas rumah kaca dari sektor pertanian dapat dilakukan melalui strategi mitigasi, secara simultan juga perlu dilakukan pengkajian dan analisis tentang kapasitas dan laju penyerapan gas rumah kaca pada sektor pertanian (Surmaini et.al, 2011).

\section{Penelitian}

Mambu

menyimpulkan bahwa hasil perhitungan jumlah produksi emisi metan pada lahan padi sawah di Kabupaten Minahasa Provinsi Sulawesi Utara menunjukkan terjadinya kenaikan total emisi metan per tahun (data tahun 2002-2010). Penelitian Murniyanto (2011) juga menunjukkan bahwa perhitungan emisi metan untuk aktivitas pertanian khususnya padi sawah di Jawa Timur mengalami peningkatan dari 2.310.728 ton pada tahun 2000 menjadi 3.157.000 ton pada tahun 2010. Peningkatan emisi metan dari penelitian tersebut diantaranya disebabkan oleh penggunaan jenis varietas, penggenangan sawah, penggunaan pupuk anorganik serta penambahan frekuensi luas pertanaman lahan sawah.

Menghadapi kenaikan emisi metan tersebut, pemerintah Indonesia telah berkomitmen untuk menurunkan emisi gas rumah kaca secara nasional hingga $26 \%$ pada tahun 2020 dengan menggunakan sumber pendanaan dalam negeri, serta penurunan emisi hingga $41 \%$ jika ada dukungan internasional dalam aksi mitigasi (Badan Perencanaan Pembangunan Nasional, 2010).

Berdasarkan Rencana Aksi Nasional dalam menghadapi perubahan iklim yang diterbitkan oleh Kementrian Negara Lingkungan Hidup tahun 2007, berbagai sektor kehidupan di Indonesia termasuk sektor pertanian perlu melakukan mitigasi dan adaptasi terhadap perubahan iklim. Memperhatikan rencana ini, produksi pertanian khususnya padi 
di masa mendatang bukan hanya ditujukan untuk stabilitas ketahanan pangan saja, tetapi juga untuk mitigasi emisi gas metan dan stabilitas ketahanan energi (Ahyar et.al, 2012). Pengurangan emisi gas metan ini dapat mengurangi dampak gas rumah kaca dan perubahan iklim terhadap sektor pertanian dengan meningkatkan produktivitas dan pengurangan lahan yang digunakan (Olander et.al, 2014).

Sektor pertanian dari emisi metan merupakan penyumbang gas rumah kaca akan berpengaruh terhadap kenyamanan dan keberlanjutan produksi pertanian (Wihardjaka, 2007). Salah satu upaya yang dilakukan adalah dengan melakukan mitigasi emisi gas metan secara periodik melalui karakteristik lahan dan pengukuran besarnya emisi gas metan, beserta perhitungan kontribusinya terhadap pemanasan global (Suntoro et.al, 2013).

Seluruh pihak termasuk masyarakat perlu terus didorong untuk melakukan tindakan mitigasi yang akan memberikan kontribusi terhadap pengurangan emisi gas rumah kaca secara global. Upaya adaptasi dan mitigasi perubahan iklim dapat terintegrasi dengan kegiatan pengelolaan lingkungan yang telah dilakukan masyarakat ditingkat lokal dengan memperhatikan faktor resiko iklim dan dampak perubahan iklim yang mungkin terjadi.

Pendataan aksi lokal adaptasi dan mitigasi perubahan iklim dapat dilaksanakan melalui pendekatan yang bersifat bottom-up, yaitu dengan mendorong berbagai pihak untuk mengumpulkan informasi dan dapat memberikan manfaat yang nyata terhadap upaya penanganan perubahan iklim. Pendataan dan pengukuran manfaat tersebut dibatasi pada luasan tertentu dengan menggunakan terminologi "Kampung Iklim". Kampung Iklim merupakan lokasi yang masyarakatnya telah melakukan upaya adaptasi dan mitigasi perubahan iklim secara berkesinambungan dan terorganisasi dengan baik. (Peraturan Mentri Lingkungan Hidup, 2012). Salah satu desa program Kampung.

Iklim di Indonesia adalah Desa Mukti Jaya yang terletak di Kecamatan Rimba Melintang, Kabupaten Rokan Hilir, Provinsi Riau.

Sejak tahun 2012, desa Mukti Jaya telah melakukan berbagai kegiatan adaptasi dan mitigasi di berbagai sektor terutama pertanian. Penggunaan lahan untuk sektor pertanian mencapai $21,67 \%$ dan sebanyak $56,01 \%$ dari penduduk desa Mukti Jaya bermata pencaharian sebagai petani. Sampai saat ini belum memiliki data yang lengkap mengenai jumlah emisi metan sektor pertanian, nilai ekonomi, partisipasi dan motivasi masyarakat terhadap program Kampung Iklim.

Penelitian tentang emisi gas rumah kaca sektor pertanian yang disebabkan oleh emisi metan telah banyak dilakukan, namun ketersediaan informasi mengenai model emisi metan sektor pertanian terutama di desa program Kampung Iklim sampai saat ini belum tersedia. Nilai ekonomi dan sosial berupa partisipasi masyarakat juga berpengaruh terhadap besarnya emisi metan sektor pertanian budidaya padi sawah.

$$
\text { Penelitian Najamuddin }
$$

menyarankan agar dalam mempertahankan swasembada beras tetapi mampu menurunkan emisi gas rumah kaca sehingga perlu menerapkan mitigasi sektor pertanian, perlu sosialisasi secara massif dan luas kepada petani/kelompok tani terkait dengan dampak, strategi mitigasi dan adaptasi perubahan iklim dalam rangka mempertahankan dan mengembangkan usahatani komoditas pangan khusunya padi yang efisien, ramah lingkungan dan berkelanjutan. Hal ini menjadi perhatian dan penting untuk diteliti karena akan memberikan gambaran secara menyeluruh tentang reduksi emisi metan sektor pertanian serta mampu mengestimasi jumlah emisi metan di tahun mendatang.

Tujuan Penelitian untuk menganalisa nilai emisi metan sektor pertanian di Desa Mukti Jaya Kecamatan Rimba Melintang Kabupaten Rokan Hilir Provinsi Riau.

Manfaat Penelitian dapat digunakan sebagai bahan kajian untuk daerah Kampung Iklim lain sehingga pengelolaan lahan pertanian padi sawah menghasilkan emisi yang rendah.

\section{BAHAN DAN METODE}

Emisi metan dihitung dengan mengalikan faktor emisi harian dengan lama budidaya padi sawah dan luas panen dengan menggunakan persamaan: 
$\mathrm{CH}_{4}$ Rice $=\sum_{\mathrm{ijk}}\left(\mathrm{EF}_{\mathrm{i}, \mathrm{j}, \mathrm{k}} \times \mathrm{t}_{\mathrm{i}, \mathrm{j}, \mathrm{k}} \times \mathrm{A}_{\mathrm{i}, \mathrm{j}, \mathrm{k}} \times 1^{-6}\right)$ dimana:

$\mathrm{CH}_{4}$ Rice = Emisi metana dari budidaya padi sawah, $\mathrm{Gg} \mathrm{CH}_{4}$ per tahun

$\mathrm{EF}_{\mathrm{i}, \mathrm{j}, \mathrm{k}} \quad=$ Faktor emisi untuk kondisi i,j dan

$\mathrm{k}$; hari

$\mathrm{t}_{\mathrm{i}, \mathrm{j}, \mathrm{k}} \quad=$ Lama budidaya padi sawah untuk kondisi i,j dan k; ha pertahun

$\mathrm{i}, \mathrm{j}$ dan $\mathrm{k}=$ Mewakili ekosistem berbeda $\mathrm{i}$ :rezim air, j: jenis dan jumlah pengembalian bahan organik tanah, dan k: kondisi lain dimana emisi $\mathrm{CH}_{4}$ dari padi sawah dapat bervariasi

Jenis sawah dapat dikelompokkan menjadi tiga rejim air yaitu sawah irigasi (teknis, setengah teknis dansederhana), sawah tadah hujan dan sawah dataran tinggi. Hal ini perlu dipertimbangkan karena kondisi (i,j,k dst) mempengaruhi emisi $\mathrm{CH}_{4}$. Emisi untuk masingmasing sub unit (ekosistem) disesuaikan dengan mengalikan faktor emisi dengan berbagai skala. Persamaan yang digunakan adalah sebagai berikut :

$\mathrm{EF}_{\mathrm{i}}=\left(\mathrm{EF}_{\mathrm{c}} \times \mathrm{SF}_{\mathrm{w}} \times \mathrm{SF}_{\mathrm{p}} \times \mathrm{SF}_{\mathrm{o}} \times \mathrm{SFs}, \mathrm{r}\right)$

dimana:

$\mathrm{EF}_{\mathrm{i}}=$ Faktor emisi harian yang terkoreksi untuk luas panen tertentu, $\mathrm{kg}$ $\mathrm{CH}_{4}$ per hari

$\mathrm{Ef}_{\mathrm{c}}=$ Faktor emisi baseline untuk padi sawah dengan irigasi terus-menerus dan tanpa pengembalian bahan organik

$\mathrm{SF}_{\mathrm{w}}=$ Faktor skala yang menjelaskan perbedaan rejim air selama periode budidaya

$\mathrm{SF}_{\mathrm{p}}=$ Faktor skala yang menjelaskan perbedaan rejim air sebelum budidaya

$\mathrm{SF}_{\mathrm{o}}=$ Faktor skala yang menjelaskan jenis dan jumlah pengembalian bahan organik yang diterapkan selama periode budidaya padi sawah

$\mathrm{SF}_{\mathrm{s}, \mathrm{r}}=$ Faktor skala untuk jenis tanah, varietas padi sawah dan lain-lain, jika tersedia

Faktor skala untuk penggunaan bahan organik dihitung berdasarkan jumlah bahan organik yang diberikan dalam periode budidaya dengan persamaan berikut :

$\mathrm{Sf}_{\mathrm{o}}=\left(1+\mathrm{ROA}_{\mathrm{t}} \mathrm{x} \mathrm{CFOA}_{\mathrm{i}}\right)^{0,59}$ dimana:
$\mathrm{Sf}_{\mathrm{o}}=$ faktor skala untuk jenis bahan organik yang digunakan

$\mathrm{ROA}_{\mathrm{t}}=$ jumlah bahan organik yang digunakan, dalam berat kering atau berat segar, ton/ha

$\mathrm{CFOA}_{\mathrm{i}}=$ faktor konversi bahan organik

\section{HASIL}

Berdasarkan formulasi IPCC (2006) tentang penghitungan emisi metan dari pengelolaan padi sawah di desa Mukti Jaya, diperoleh nilai emisi metan lahan pertanian padi sawah pada tahun 2011 sebesar 0,032 $\mathrm{Gg} \mathrm{CH}_{4} /$ tahun. Tahun 2012, emisi yang dihasilkan meningkat menjadi 0,039 $\mathrm{Gg} \mathrm{CH}_{4} /$ tahun. Penurunan emisi metan terjadi pada tahun 2013. Nilai emisi pada tahun tersebut adalah $0,038 \quad \mathrm{Gg} \quad \mathrm{CH}_{4} /$ tahun. Selanjutnya, pada tahun 2014 kembali terjadi peningkatan jumlah emisi metan menjadi 0,043 $\mathrm{Gg} \mathrm{CH}_{4} /$ tahun. Jumlah emisi pada tahun 2014 merupakan emisi tertinggi dibandingkan dengan tahun-tahun sebelumnya. Tahun 2015 terjadi penurunan nilai emisi namun tidak terlalu besar. Nilai emisi pada tahun 2015 adalah 0,041 Gg $\mathrm{CH}_{4} /$ tahun. Emisi metan yang dihasilkan dari pengelolaan padi sawah dari tahun 2011-2015 dapat dilihat pada grafik berikut :

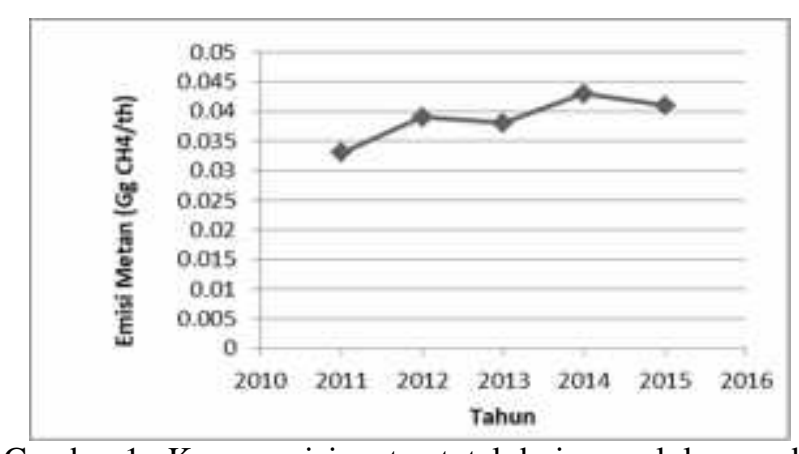

Gambar 1. Kurva emisi metan total dari pengelolaan padi sawah di Desa Mukti Jaya pada tahun 20112015

Berdasarkan data penggunaan lahan sawah dari masing-masing varietas, maka dengan menggunakan persamaan IPCC 2006 untuk setiap tahunnya diperoleh nilai emisi metan seperti pada tabel berikut : 
Tabel 1. Emisi metan masing-masing varietas padi

\begin{tabular}{cccccc}
\hline Varietas & \multicolumn{5}{c}{ Jumlah emisi metan $\left(\mathrm{Gg} \mathrm{CH}_{4} /\right.$ tahun $)$} \\
\cline { 2 - 6 } Ciherang & 0,026 & 0,010 & 0,013 & 0,011 & 0,013 \\
Dodokan & 0,004 & 0,014 & 0,011 & 0,011 & 0,009 \\
Cisadane & 0,002 & 0,015 & 0,014 & 0,021 & 0,019 \\
Emisi & 0,032 & 0,039 & 0,038 & 0,043 & 0,041 \\
Total & & & & &
\end{tabular}

Sumber: Data Olahan, 2015

Jumlah emisi metan masing-masing varietas dapat dilihat pada grafik berikut:

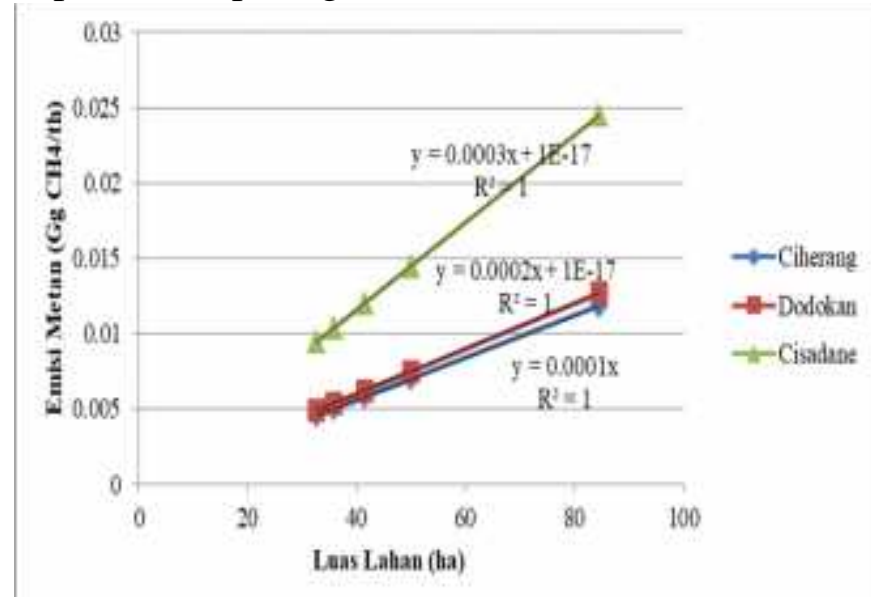

Gambar 2. Emisi metan varietas padi

\section{PEMBAHASAN}

Berdasarkan formulasi IPCC (2006) tentang penghitungan emisi metan dari pengelolaan padi sawah di desa Mukti Jaya, diperoleh nilai emisi metan lahan pertanian padi sawah pada tahun 2011 sebesar 0,032 Gg CH $4 /$ tahun. Tahun 2012, emisi yang dihasilkan meningkat menjadi 0,039 Gg $\mathrm{CH}_{4} /$ tahun. Penurunan emisi metan terjadi pada tahun 2013. Nilai emisi pada tahun tersebut adalah $0,038 \quad \mathrm{Gg} \quad \mathrm{CH}_{4} /$ tahun. Selanjutnya, pada tahun 2014 kembali terjadi peningkatan jumlah emisi metan menjadi 0,043 Gg $\mathrm{CH}_{4} /$ tahun. Jumlah emisi pada tahun 2014 merupakan emisi tertinggi dibandingkan dengan tahun-tahun sebelumnya. Tahun 2015 terjadi penurunan nilai emisi namun tidak terlalu besar. Nilai emisi pada tahun 2015 adalah $0,041 \mathrm{Gg}$ $\mathrm{CH}_{4} /$ tahun.

Jumlah $\mathrm{CH}_{4}$ yang diemisikan merupakan fungsi dari beberapa parameter seperti umur tanaman, rejim air sebelum dan selama periode budidaya, dan penggunaan bahan organik dan anorganik. Selain itu, emisi metan juga dipengaruhi oleh jenis tanah dan varietas padi. Berdasarkan data yang diperoleh dari tahun 2011 hingga 2015, ada beberapa faktor yang tidak mengalami perubahan dan ada juga faktor yang mengalami perubahan setiap tahunnya. Parameter yang berubah adalah dosis pupuk organik yang digunakan serta varietas.

Gambar 2 menampilkan hubungan antara luas lahan terhadap emisi metan yang dihasilkan oleh tiga varietas padi yaitu Ciherang, Dodokan dan Cisadane. Dari gambar dapat dilihat bahwa varietas Cisadane memiliki tingkat emisi metan yang lebih besar dibandingkan varietas Ciherang dan Dodokan. Varietas Cisadane memiliki tingkat perubahan emisi yang lebih cepat terhadap perubahan luas lahan. Dalam perumusan ini, sumbu vertikal adalah tingkat emisi dan sumbu horizontal adalah luas lahan. Nilai kemiringan ini hampir dua kali lebih besar dibandingkan varietas Ciherang dan Dodokan.

Hasil penelitian Setyanto (2006) terhadap pengujian beberapa varietas padi sawah irigasi sejak tahun 1995 oleh Balai Penelitian Lingkungan Pertanian Jakenan menunjukkan bahwa varietas Cisadane mengemisi metana paling tinggi jika dibandingkan dengan varietas Ciherang, sedangkan IR36 dan dodokan paling rendah. Demikian pula hasil penelitian Setyanto et al. (2004), pada hari ke 57 setelah pindah tanam, menunjukkan rata - rata emisi metan paling tinggi pada plot yang ditanam dengan varietas Cisadane dan emisi yang terendah berada pada varietas IR 64.

Hasil pengujian beberapa varietas padi di sawah irigasi dan tadah hujan maupun sawah pasang surut, menunjukkan bahwa varietas Cisadane mengemisi metana paling tinggi sebesar $218 \mathrm{~kg} \mathrm{CH} 4 /$ ha, sedangkan IR36 dan Dodokan paling rendah yaitu sebesar $74 \mathrm{~kg}$ $\mathrm{CH}_{4} /$ ha. Cisadane diduga mempunyai kemampuan fotosintesis lebih baik dari varietas lainnya hingga eksudat akar yang dihasilkan lebih mudah terdegradasi. Sebaliknya IR36 dan Dodokan diduga mempunyai kapasitas pengoksidasi akar yang lebih baik dari varietas lain sehingga konsentrasi akar meningkat dan metana teroksidasi secara biologis oleh bakteri metanotropik (Balai Penelitian Pertanian, 2006). 
Perbedaan emisi $\mathrm{CH}_{4}$ yang dihasilkan dari ketiga varietas salah satunya ditentukan oleh perbedaan morfologi dan fisiologi varietas, serta kemampuan akar mengoksidasi $\mathrm{CH}_{4}$ dan eksudasi antar varietas. Menurut Dubey (2005), perbedaan rongga aerenkhima antarvarietas padi menentukan tingkat emisi $\mathrm{CH}_{4}$. Lebih dari $50 \%$ $\mathrm{CH}_{4}$ yang dilepaskan ke tanah sawah disebabkan oleh eksudasi akar (Dannerberg dan Conrad, 1999). Eksudat akar yang antara lain berupa asetat dan formiat memberikan kontribusi tinggi terhadap pembentukan metan (Watanabe et al, 1995). Lebih dari $80 \%$ asetat digunakan sebagai substrat karbon untuk pembentukan $\mathrm{CH}_{4}$, dan $10-30 \%$ berasal dari $\mathrm{H}_{2} / \mathrm{CO}_{2}$ dan formiat.

Menurut Aulakh et.al (2001), tanaman padi mempunyai kemampuan berbeda dalam melepaskan eksudat akar dalam tanah, bergantung pada efisiensi pemanfaatan fotosintat oleh tanaman. Semakin efisien tanaman memanfaatkan fotosintat (untuk pembentukan gabah dan organ lainnya), semakin kecil eksudat akar yang terlepas ke tanah dan semakin rendah emisi $\mathrm{CH}_{4}$.

Hasil penelitan Mambu (2012) di daerah Kabupaten Minahasa, pada tahun 2012 lahan pertanian yang ditanami varietas Ciherang seluas 13,465 ha, menghasilkan emisi sebesar $1,731 \mathrm{Gg} \mathrm{CH}_{4} /$ th. Perhitungan besarnya emisi untuk satu hektar lahan, maka emisi yang dihasilkan adalah sebesar $0,1289 \mathrm{Gg} \mathrm{CH}_{4} /$ th .

Jumlah emisi ini lebih besar bila dibandingkan dengan desa Mukti Jaya yang hanya menghasilkan emisi sebesar $0,00014 \mathrm{Gg}$ $\mathrm{CH}_{4} /$ th. Untuk varietas Cisadane pada tahun 2012 dengan luas lahan pertanian 13,465 ha, menghasilkan emisi sebesar 3,085 $\mathrm{Gg} \mathrm{CH}_{4} /$ th. Untuk satu hektar lahan diperoleh emisi sebesar $0,229 \mathrm{Gg} \mathrm{CH}_{4} /$ th. Nilai emisi tersebut lebih besar dari desa Mukti Jaya yang hanya sebesar 0,00029 $\mathrm{Gg} \mathrm{CH}_{4} /$ th. Faktor - faktor yang mempengaruhi produksi emisi gas metana pada lahan padi sawah di Kabupaten Minahasa yaitu penggunaan jenis varietas Cisadane yang termasuk dalam varietas tinggi emisi $\mathrm{CH}_{4}$, penggenangan sawah menggunakan jenis pengairan terus - menerus, penggunaan pupuk anorganik yang tidak efisien baik dalam jumlah maupun waktu pemberian, dan penggunaan bahan organik (jerami padi) yang dibenamkan setelah panen tanpa melalui proses pengomposan (Mambu, 2012).

Pawitan et al (2008) telah mengompilasi berbagai varietas padi dan tingkat emisinya dan merekomendasikan penggunaan beberapa varietas rendah emisi antara lain Maros dengan emisi $74 \mathrm{~kg} \mathrm{CH} / \mathrm{ha} /$ musim,Way Rarem 91,60 $\mathrm{kg} \quad \mathrm{CH}_{4} / \mathrm{ha} /$ musim, Limboto 99,20 $\mathrm{kg}$ $\mathrm{CH}_{4} / \mathrm{ha} /$ musim, dan Ciherang dengan emisi $114,80 \mathrm{~kg} \mathrm{CH}_{4} / \mathrm{ha} /$ musim. Varietas padi yang dominan ditanam petani adalah IR64. Namun, saat ini petani mulai mengganti IR64 dengan varietas yang serupa yaitu Ciherang. Selain lebih tahan terhadap hama dan penyakit,varietas Ciherang juga lebih rendah mengemisi gas metan. Untuk itu penanaman varietas Ciherang yang makin luas akan mengurangi emisi gas rumah kaca dari lahan pertanian.

\section{SIMPULAN}

Emisi metan lahan pertanian padi di desa Mukti Jaya dari tahun 2011-2015 mengalami peningkatan disebabkan oleh perubahan beberapa parameter penghasil metan. Penggunaan varietas Cisadane menghasilkan emisi metan tertinggi dibandingkan varietas Ciherang dan Dodokan yaitu sebesar 0,00029 $\mathrm{Gg} \mathrm{CH}_{4} /$ th/ha

\section{UCAPAN TERIMA KASIH}

Ucapan terima kasih penulis ucapkan kepada pihak-pihak yang telah membantu dalam terlaksananya penelitian ini.

\section{DAFTAR PUSTAKA}

Ahyar, M. Azis, NB. Widada. S. 2012. Perilaku Bertani Padi Sawah yang Mitigatif Terhadap Perubahan Iklim di Kabupaten Bima. Prosiding Seminar Nasional Pengelolaan Sumber Daya Alam dan Lingkungan. Semarang. 11 September 2012

Aulakh, M.S., Bodenbender, J., Wassmann, R., and Rennenberg, H. 2001. Metthane Transport Capacity of Rice Plant. II. Variations Among Different Rice Cultivars and Relationship with Morphologycal Characteristic. Nutrient Cyling Agroecosystem 
Intergovermental Panel on Climate Change. 2006. Guidelines for National Greenhouse Gas Inventories Volume 4. Agriculture, Forestry and Other Land Use

Kementerian Negara Lingkungan Hidup Republik Indonesia, 2007. Rencana Aksi Nasional dalam Menghadapi Perubahan Iklim. Jakarta

Mambu, S.M. 2012. Pendugaan Emisi Metana Pada Sistem Pengelolaan Tanaman Padi di Kabupaten Minahasa. Jurnal Bioslogos. Februari 2012. Vol 2 Nomor 2

Mulyadi dan A. Wihardjaka. 2014. Emisi Gas Rumah Kaca dan Hasil Gabah dari Tiga Varietas Padipada Lahan Sawah Tadah Hujan Bersurjan. Penelitian Pertanian Tanaman Pangan Vol 33 No.2 Tahun 2014

Murniyanto, E., Karuniawan, PW. Firman, M. 2011. Analisis Emisi $\mathrm{CH}_{4}$ dan Serapan $\mathrm{CO}_{2}$ Aktivitas Pertanian di Jawa Timur. Jurnal Agrovigor Volume 4 (1): 51-61 Maret 2011, ISSN 1979 -5777

Peraturan Presiden No.61 Tahun 2012 Tentang rencana Aksi Penurunan Emisi Gas Rumah Kaca (RAN-GRK)

Setyanto, P. 2006. Varietas Padi Rendah Emisi Gas Rumah Kaca. Penelitian dan Pengembangan Pertanian Vol. 28 No. 4
Suntoro, Mujiyo.Jauhari Syamsiah. 2013. Kontribusi Budidaya Tanaman Pangan Terhadap Potensi Emisi $\mathrm{N}_{2} \mathrm{O}$ dan Sumbangannya pada Global WarmingPotential Jurnal Ekosains Vol V No.2 Juli 2013

Surmaini, E. Eleonora,R dan Irsal, L. 2011. Upaya Sektor Pertanian dalam Menghadapi Perubahan Iklim. Jurnal Litbang Pertanian, 30 (1)

US-EPA (United States Environmental Protection Agency). 2006. Global Anthropogenic Non $\mathrm{CO}_{2}$ Green House Gas Emission: 1990-2020. EPA 430-R06-003, June 2006. Washington, D.C

Wihardjaka, A. dan Setyanto, P. 2007. Emisi dan Mitigasi Gas Rumah Kaca dari Lahan Sawah Irigasi dan Tadah Hujan. Dalam: Pengelolaan Lingkungan Pertanian Menuju Mekanisme Pembangunan Bersih. Balai Penelitian Lingkungan Pertanian. Balai Besar Penelitian dan Pengembangan Sumber Daya Lahan Pertanian. Badan Penelitian dan Pengembangan Pertanian. Departemen Pertanian. Jakenan. Pati

Zhang. 2014. Uncertainties in Estimating Regional Methane Emissions from Rice Paddies Due to Data Scarcity in the Modeling Approach. Geosci. Model Dev., 7, 1211-1224, 2014. www.geoscimodel-dev.net/7/1211/2014. doi: 10.5194/gmd-7-1211-2014 